\author{
MARCIN PLEŚNIAK \\ Uniwersytet Wrocławski \\ e-mail: marcin.plesniak@uwr.edu.pl
}

\title{
Formy współpracy administracji publicznej z organizacjami pozarządowymi — na przykładzie stowarzyszeń i fundacji
}

\section{Wprowadzenie}

Celem niniejszego artykułu jest zebranie i scharakteryzowanie form współpracy pomiędzy organami administracji publicznej a organizacjami pozarządowymi. Spośród wielu podmiotów wchodzących w zakres trzeciego sektora najbardziej reprezentatywne i najliczniejsze są stowarzyszenia i fundacje, które są zaliczane do tzw. wąskiej definicji sektora organizacji pozarządowych ${ }^{1}$. Zgodnie z danymi z końca 2014 r. według rejestru REGON w Polsce było zarejestrowanych 86 tys. stowarzyszeń i 17 tys. fundacji ${ }^{2}$. Pozostałych podmiotów zaliczanych do szeroko rozumianego trzeciego sektora, tj. spółdzielni socjalnych, kół łowieckich, kół gospodyń wiejskich czy instytucji kościelnych, a nawet partii politycznych, jest ok. 50 tys. ${ }^{3}$ Istnieje wiele form finansowej i pozafinansowej współpracy, które warto zebrać i chociaż pokrótce scharakteryzować. Zgromadzenie w jednym miejscu wszystkich dotychczasowych form współpracy wydaje się potrzebne ze względu na dynamiczny rozwój trzeciego sektora i jego coraz większe znaczenie w wykonywaniu zadań publicznych. Omawiane formy współpracy będą poparte praktycznymi przykładami z terenu województwa dolnośląskiego, a nawet węziej - miasta Wrocławia, w którym autor zamieszkuje.

${ }^{1}$ Kondycja sektora organizacji pozarządowych w Polsce 2015, raport z badań Stowarzyszenia Klon, Jawor 2016, s. 27.

2 Ibidem.

${ }^{3}$ http://fakty.ngo.pl/liczba-ngo (dostęp: 17.09.2017). 
Artykuł został przygotowany w oparciu o fachową literaturę przedmiotu, raporty z badań sektora organizacji pozarządowych oraz praktyczne przykłady z terenu miasta Wrocławia.

\section{Charakterystyka fundacji i stowarzyszeń}

Jak już zostało wspomniane, fundacje i stowarzyszenia są najpopularniejszymi formami działalności społecznej. Nie wdając się w rozważania historyczne, trzeba stwierdzić, że korzenie obu form prawnych sięgają czasów rzymskich ${ }^{4}$.

W polskim porządku prawnym swobodę tworzenia fundacji zapewnia już Konstytucja Rzeczypospolitej Polskiej ${ }^{5}$ w art. 12, natomiast podstawowe kwestie, takie jak powstawanie, likwidację, wymogi statutowe, zasady kontroli i zasady powoływania przedstawicielstw fundacji zagranicznych, określa Ustawa z dnia 6 kwietnia 1984 r. o fundacjach ${ }^{6}$. W art. 1 ustanawia przykładowe (jak wskazuje doktryna, nie jest to katalog zamknięty) ${ }^{7}$ cele fundacji, stanowiąc, że fundacja może być ustanowiona dla realizacji zgodnych z podstawowymi interesami Rzeczypospolitej Polskiej celów społecznie lub gospodarczo użytecznych, w szczególności takich jak: ochrona zdrowia, rozwój gospodarki i nauki, oświata i wychowanie, kultura i sztuka, opieka i pomoc społeczna, ochrona środowiska oraz opieka nad zabytkami. Fundacja jest osobą prawną typu zakładowego, majątkowego. Fundatorem w myśl art. 2 ustawy może być osoba fizyczna (niezależnie od obywatelstwa czy miejsca zamieszkania) i prawna (bez względu na umiejscowienie siedziby). Sama siedziba fundacji powinna być jednak zlokalizowana w Polsce. Fundator winien ustanowić fundację w formie aktu notarialnego, w którym musi zostać zawarty cel lub cele fundacji, a także środki przeznaczone na jego lub ich realizację (art. 3 ust. 1-2 ustawy o fundacjach). Składnikami tworzącymi majątek fundacji mogą być — w myśl art. 3 ust. 3 - pieniądze, papiery wartościowe oraz oddane na własność ruchomości i nieruchomości.

Artykuł 5 określa obligatoryjne i fakultatywne elementy treści statutu fundacji, nadawanego przez fundatora bądź w jego imieniu przez inną osobę fizyczną albo prawną. Obligatoryjnymi elementami statutu są: nazwa, siedziba i majątek, cele, zasady, formy i zakres działalności fundacji, skład i organizacja zarządu, sposób powoływania oraz obowiązki i uprawnienia tego organu i jego członków. Fakultatywnymi elementami są natomiast: dopuszczalność prowadzenia działalności gospodarczej, dopuszczalność połączenia z inną fundacją, zmiany celów statutowych, zmiany samego statutu, a także tworzenie obok zarządu innych or-

4 K. Kolańczyk, Prawo rzymskie, Warszawa 2000, s. 245-248.

5 Dz.U. z 1997 r. Nr 78, poz. 483.

6 Tekst jedn. Dz.U. z 2016 r. poz. 40.

7 H. Cioch, A. Kidyba, Ustawa o fundacjach. Komentarz, Warszawa 2007, s. 5. 
ganów fundacji. Fundacja podlega wpisowi do Krajowego Rejestru Sądowego (art. 7 ust. 1 ustawy o fundacjach). Osobowość prawną i możliwość działania nabywa ona $\mathrm{z}$ chwilą wpisu do KRS (art. 7 ust. 2 ustawy o fundacjach).

Podstawy tworzenia stowarzyszeń również wynikają z Konstytucji (art. 12 oraz art. 58 ust. 1., tj. wolność zrzeszania się). Podstawą prawną działalności stowarzyszeń jest Ustawa z dnia 7 kwietnia 1989 r. - Prawo o stowarzyszeniach ${ }^{8}$. W myśl art. 2 ust. 1 stowarzyszenie jest dobrowolnym, samorządnym, trwałym zrzeszeniem o celach niezarobkowych. Akcentowana jest dobrowolność zrzeszania (prawo o stowarzyszeniach $\mathrm{w}$ art. 6 ust. 1 wprost zakazuje tworzenia stowarzyszeń wymagających bezwzględnego posłuszeństwa członków wobec władz). Co do zasady — inaczej niż przy fundacjach — prawo tworzenia stowarzyszeń przysługuje obywatelom polskim o pełnej zdolności do czynności prawnych (art. 3 ust. 1 prawa o stowarzyszeniach). Również cudzoziemcy mają taką możliwość, lecz tylko zamieszkali na terytorium RP. Stowarzyszenie podlega obowiązkowemu wpisowi do KRS (art. 8 prawa o stowarzyszeniach). Stowarzyszenia są osobami prawnymi typu korporacyjnego, zrzeszeniowego. Głównym substratem są ludzie, a nie majątek. W zasadzie nie jest on konieczny w chwili powstania stowarzyszenia. Artykuł 9 Prawa o stowarzyszeniach wymaga dla założenia stowarzyszenia min. 7 osób, które wybierają komitet założycielski bądź władze stowarzyszenia. Tak jak fundacje, podstawą działalności stowarzyszeń prócz aktów powszechnie obowiązujących są ich statuty. Elementy treści statutu stowarzyszeń zawiera art. 10 prawa o stowarzyszeniach.

Do obligatoryjnych elementów statutu stowarzyszenia należą: nazwa stowarzyszenia, odróżniająca je od innych podmiotów; teren działania i siedziba stowarzyszenia; cele i sposoby ich realizacji; sposób nabywania i utraty członkostwa, przyczyny utraty członkostwa oraz prawa i obowiązki członków; władze stowarzyszenia, tryb ich wyboru, uzupełniania i ich kompetencje; możliwość otrzymywania przez członków zarządu wynagrodzenia w związku z pełnioną funkcją; sposób reprezentowania stowarzyszenia, w szczególności sposób zaciągania zobowiązań majątkowych, a także warunki ważności uchwał władz stowarzyszenia; sposób uzyskiwania środków finansowych oraz ustanawiania składek członkowskich; zasady dokonywania zmian statutu; sposób rozwiązania stowarzyszenia.

W przeciwieństwie do fundacji, obligatoryjnymi organami władz stowarzyszenia są zarząd i organ kontroli wewnętrznej, nazywany często komisją rewizyjną. Ponieważ stowarzyszenie jest zrzeszeniem osób, jego najważniejszym organem jest walne zebranie członków lub delegatów.

Na koniec tej ogólnej charakterystyki warto dodać, iż oba podmioty mogą prowadzić działalność gospodarczą, akcesoryjną w stosunku do działalności statutowej.

8 Tekst jedn. Dz.U. z 2017 r. poz. 210. 


\section{Pojęcie administracji publicznej i organów administracji publicznej}

W potocznym rozumieniu słowo ,administracja” można pojmować jako synonim pomocy, służby, przewodnictwa, kierownictwa, prowadzenia, zarządu i zarządzania. Jak wskazuje Jan Boć w swoim podręczniku Prawo administracyjne, „[w] zależności od kontekstu termin ten może odnosić się do czynności lub osób je podejmujących, lub też jednocześnie i do podmiotów, i ich czynności"”. W ujęciu prawnym termin ten podawany jest też jako zawężenie pojęcia „rządzenie”"10. Dodanie przymiotnika „publiczna” zawęża obszar poszukiwań definicyjnych do działań realizujących interes publiczny, niejednostkowy.

Inni przedstawiciele doktryny nie wskazują jednej prostej definicji administracji publicznej. Jak stwierdza Jan Zimmermann:

Nauka prawa administracyjnego usiłowała od samego początku ująć pojęcie administracji publicznej w ramy ścisłej definicji. Powstały dzięki temu dziesiątki albo setki definicji, które miały pewną wartość poznawczą, ale nigdy nie osiągnięto definicji doskonałej i pełnej ${ }^{11}$.

Wydaje się zatem bardziej zasadne na potrzeby niniejszego artykułu wskazanie cech znamionujących działalność administracji publicznej niż konstruowanie zamkniętej definicji. Będą to — za wskazaniem J. Zimmermanna — następujące cechy:

1) działanie administracji w imieniu państwa i na jego rachunek;

2) możliwość stosowania przymusu państwowego i używania władztwa administracyjnego;

3) stopniowalność owego władztwa administracyjnego, zależna od funkcji administracji — wyróżniamy m.in. administrację władczą (imperium) i zawiadowczą (dominium) i dalsze, bardziej szczegółowe, podziały;

4) działanie administracji na podstawie i w granicach prawa rangi ustawowej;

5) działania wykonawcze, konkretyzujące zapisy ustawowe;

6) obowiązek korzystania administracji publicznej z kompetencji nakładanych przez prawo;

7) organizacja życia społecznego na podległym jej terenie w granicach jej kompetencji wyznaczanych przez prawo;

8) działanie administracji jest ciągłe i stabilne, a proces administrowania stały;

9) fachowość i profesjonalizm kadry urzędniczej administracji publicznej, podlegającej odpowiedzialności prawnej za jej działania;

\footnotetext{
9 Prawo administracyjne, red. J. Boć, Wrocław 2010, s. 12.

10 Ibidem.

11 J. Zimmermann, Prawo administracyjne, Warszawa 2012, s. 29.
} 
10) monopolistyczny charakter administracji publicznej — jest ona jedna $\mathrm{w}$ danym państwie, niezależnie od rodzaju sprawujących ją organów ${ }^{12}$.

Administracja publiczna działa za pośrednictwem swoich organów. Nie wdając się w kwestie definicyjne, które też nastręczają trudności, trzeba stwierdzić, że są to osoby bądź zespoły osób wyposażonych w kompetencje i możliwość stosowania władztwa administracyjnego, wyraźnie wyodrębnione prawnie od innych organów ${ }^{13}$.

Odnosząc się już bezpośrednio do współpracy administracji publicznej i podmiotów trzeciego sektora, należy wskazać, że po stronie administracji publicznej obowiązkiem współpracy będą objęte wszystkie organy, którym przepisy prawa takie zadania współdziałania wyznaczają. Będą to organy administracji rządowej, $\mathrm{w}$ większej mierze organy jednostek samorządu terytorialnego (nazywane dalej JST), aczkolwiek w literaturze wskazuje się również organy naczelne administracji publicznej, np. Prezydenta $\mathrm{RP}^{14}$.

\section{Formy współpracy administracji publicznej i organizacji pozarządowych}

Ramy współpracy trzeciego sektora z administracją publiczną zakreśla swoista „konstytucja” dla działalności organizacji pozarządowych, tj. Ustawa z dnia 24 kwietnia 2003 r. o działalności pożytku publicznego i wolontariacie, zwana dalej ustawą o działalności ${ }^{15}$. W doktrynie wyróżnia się dwie zasadnicze formy współpracy:

1) finansową,

2) niefinansową ${ }^{16}$.

\section{Ad 1. Finansowa forma współpracy}

Pierwszą — i jak wskazuje praktyka, najpopularniejszą - finansową formą współpracy organizacji pozarządowych i administracji publicznej jest zlecanie realizacji zadań publicznych organizacjom pozarządowym wraz z udzielaniem dotacji celowej (art. 5 ust. 2 pkt 1 ustawy o działalności). Dotacja ta może pokrywać koszty realizacji zadania $\mathrm{w}$ całości bądź w części. Zlecanie zadań publicznych

12 J. Zimmermann, op. cit., s. 31-34.

13 Ibidem, s. 108-110.

14 R. Barański, Fundacje i stowarzyszenia. Wspótpraca organizacji pozarzadowych z administracja publiczna, Warszawa 2016, s. 346.

15 Dz.U. z 2016 r. poz. 1817.

16 Tak: R. Barański, op. cit., s. 352. 
odbywa się w dwóch formach: wspierania lub powierzania realizacji zadań publicznych organizacjom pozarządowym (art. 11 ust. 1 pkt 1-2 ustawy o działalności). Zakres zadań, a właściwie sfery zadań publicznych, wyznacza art. 4 ustawy o działalności, ustanawiający 37 sfer. Jak wskazuje Jolanta Blicharz:

Jakkolwiek katalog zadań publicznych wyznaczających rodzajowe sfery działalności pożytku publicznego ma charakter enumeratywny (wyczerpujący), to jednak jego wyczerpujący charakter osłabia możliwość określenia przez Radę Ministrów w drodze rozporządzenia dodatkowych zadań publicznych, przypisanych do sfery działalności pożytku publicznego ${ }^{17}$.

Powierzenie bądź wspieranie co do zasady następuje w trybie otwartego konkursu ofert (art. 11 ust. 2 ustawy o działalności); wyjątki zakładają przepisy ustawy o działalności, przewidziany jest również tryb wnioskowy (art. 12 ustawy o działalności).

$\mathrm{Na}$ koniec niniejszych rozważań warto zwrócić uwagę, że w przypadku młodych organizacji pozarządowych przy dotacjach częściowych powstaje spory dylemat, w jaki sposób pozyskać brakującą część sumy potrzebnej na realizację danego zadania.

Kolejnym finansowym mechanizmem wykorzystywanym przez organizacje pozarządowe, głównie stowarzyszenia i fundacje, i administrację publiczną są: gwarancje, poręczenia oraz pożyczki, udzielane głównie przez JST na realizację zadań w sferze pożytku publicznego, w ramach limitów ustalanych w budżetach państwa i JST (art. 5 ust. 2 pkt 8 ustawy o działalności).

Jednostki samorządu terytorialnego mogą udzielać pożyczek, gwarancji i poręczeń organizacjom pozarządowym oraz podmiotom zrównanym $\mathrm{w}$ prawach $\mathrm{z}$ organizacjami pozarządowymi na realizację zadań w sferze pożytku publicznego, na zasadach określonych w ustawach o samorządzie gminnym, powiatowym i województwa, ustawie o finansach publicznych oraz Kodeksie cywilnym. Umowę pożyczki oraz umowę poręczenia definiują przepisy Kodeksu cywilnego. Z uwagi na brak cywilistycznej regulacji umowy gwarancji, w praktyce JST korzystają z regulacji umowy gwarancji określonej w prawie bankowym. Procedura udzielania pożyczek i poręczeń wymaga podjęcia uchwały przez organ stanowiący JST, określający ich maksymalną wysokość w danym roku budżetowym oraz zawarcia umowy pożyczki lub poręczenia przez organ wykonawczy JST. Odmiennie, w wobec braku analogicznej regulacji ustawowej, udzielenie gwarancji przez organ wykonawczy JST nie wymaga wcześniejszej uchwały organu stanowiącego. Udzielenie pożyczki, poręczenia i gwarancji winno być związane z realizacją zadań publicznych w zakresie kompetencji JST ${ }^{18}$.

Innym mechanizmem finansowego wsparcia stowarzyszeń i fundacji jest przewidziana $\mathrm{w}$ ustawie o działalności i Ustawie z dnia 6 grudnia 2006 r. o zasadach prowadzenia polityki rozwoju ${ }^{19}$ umowa partnerska. Jest ona zawierana przez podmioty wnoszące do projektu zasoby ludzkie, organizacyjne, techniczne lub finansowe, realizujące wspólnie projekt zwany projektem partnerskim, na

17 J. Blicharz, Komentarz do ustawy o działalności pożytku publicznego i wolontariacie, [w:] eadem, Ustawa o działalności pożytku publicznego i wolontariacie. Ustawa o spótdzielniach socjalnych. Komentarz, Warszawa 2012, s. 30.

$18 \mathrm{http} / / /$ www.ekonomiaspoleczna.gov.pl/Instrumenty,wspolpracy,3893.html (dostęp: 27.06.2017).

19 Tekst jedn. Dz.U. z 2016 r. poz. 383. 
warunkach określonych w porozumieniu lub umowie partnerskiej. Są one zawierane w celu realizacji projektów finansowanych w ramach programów operacyjnych Unii Europejskiej. Instytucja umów partnerskich określa ramy prawne dla realizacji projektów wykorzystujących potencjał partnerów, dając jednocześnie możliwość angażowania członków społeczności lokalnych. W długookresowej perspektywie sprzyja ona większej integracji organów administracji z sektorem pozarządowym.

$\mathrm{Na}$ koniec przeglądu finansowych form współpracy trzeba powiedzieć kilka słów o budżecie partycypacyjnym. Jest to mechanizm, w którym obywatele oraz reprezentujące ich organizacje pozarządowe decydują bądź biorą udział w decydowaniu o przeznaczeniu całości lub części środków publicznych na konkretny cel. Jest to forma demokracji uczestniczącej, w której oddolnie obywatele (najczęściej gmin), w drodze konsultacji wyrażania swoich priorytetów, podejmują decyzje o wykorzystaniu zwykle pewnego fragmentu budżetów swoich gmin na wskazane przez siebie cele. W Polsce pierwszą gminą, która skorzystała z mechanizmu budżetu partycypacyjnego, było miasto Sopot $^{20}$.

We Wrocławiu budżet partycypacyjny funkcjonuje od 2013 r. pod nazwą Wrocławski Budżet Obywatelski. W tym właśnie roku został przeprowadzony pilotaż budżetu obywatelskiego. Od tego czasu mamy kolejne edycje Wrocławskiego Budżetu Obywatelskiego. W roku 2017 zgłoszono 725 projektów inwestycji w ramach WBO 2017, z których do głosowania dopuszczono 372 projekty — dla porównania: w 2016 r. pod głosowanie poddano 445 projektów, spośród których wybrano $70^{21}$.

\section{Ad 2. Niefinansowa forma współpracy}

Na początku należy zaznaczyć, iż ze względu na ograniczony rozmiar artykułu zostanie dokonany jedynie pobieżny przegląd niefinansowych form współpracy administracji publicznej z organizacjami pozarządowymi, z uwzględnieniem praktycznych przykładów z obszaru Wrocławia. Ich przykładowy katalog został ustanowiony w art. 5 ust. 2 ustawy o działalności, lecz trzeba pamiętać, że istnieje jeszcze wiele form mających i niemających podstaw prawnych $w$ innych ustawach. Jak wskazuje J. Blicharz,

merytoryczna (pozafinansowa) współpraca organów administracji publicznej i organizacji może mieć bardzo wiele form. Wprawdzie w wyróżnionym przepisie wymieniono kilka $\mathrm{z}$ nich, jednak katalog tych form daje organom administracji możliwość ich rozszerzania ${ }^{22}$.

20 A. Dobiegała, Budżet obywatelski to byt pomyst z kosmosu, 11.05.2016, http://trojmiasto. wyborcza.pl/trojmiasto/1,35612,20032800,nielatwe-poczatki-budzetu-obywatelskiego-w-sopocie. html (dostęp: 27.06.2017).

${ }^{21} \mathrm{http} / / /$ www.wroclaw.pl/budzet-obywatelski-wroclaw (dostęp: 17.09.2017).

22 J. Blicharz, op. cit., s. 30. 
Do niefinansowych form współpracy administracji publicznej z organizacjami trzeciego sektora zaliczamy, poczynając od tych wskazanych w ustawie o działalności:

1) Konsultacje projektów aktów normatywnych, dotyczących swoim zakresem regulacji statutowej działalności organizacji pozarządowych, np. w zakresie ochrony środowiska $\mathrm{z}$ organizacjami zajmującymi się tą dziedziną (art. 5 ust. 2 pkt 3 ustawy o działalności).

2) Konsultacje aktów normatywnych z radami pożytku publicznego różnych szczebli, o ile zostały one powołane przez JST. Akty te muszą dotyczyć sfery zadań publicznych z art. 4 ustawy o działalności (art. 5 ust. 2 pkt 4 ustawy o działalności $)^{23}$.

3) Tworzenie wspólnych zespołów doradczych i inicjatywnych (art. 5 ust. 2 pkt 5 ustawy o działalności). W tym miejscu należy wskazać Grupy Dialogu Społecznego, które są właśnie wspólnymi zespołami doradczymi, inicjatywnymi, powoływanymi z inicjatywy NGO bądź innych organów. Mają elastyczną formułę i służą prezentacji potrzeb i rozmowom pomiędzy omawianymi sektorami. Z obszaru Wrocławia można wymienić przykładowo GDS ds. zieleni miejskiej ${ }^{24}$.

4) Umowy o wykonanie inicjatywy lokalnej (art. 5 ust. 2 pkt 6 i art. 19b-h ustawy o działalności). W ramach tej inicjatywy grupa mieszkańców samodzielnie bądź za pośrednictwem organizacji pozarządowych, w tym przede wszystkim właśnie fundacji i stowarzyszeń, może zgłaszać do władz JST swojego miejsca zamieszkania lub siedziby wniosek o realizację zadania publicznego z enumeratywnego katalogu z art. 19b ustawy o działalności. Wnioski mogą dotyczyć takich zadań, jak np. sprawy z zakresu edukacji, wychowania czy kultury fizycznej i turystyki. Kryteria oceny wniosków są ustanawiane w formie uchwały organu stanowiącego danej JST, a umowę o wykonanie inicjatywy lokalnej zawiera organ wykonawczy danej JST z wnioskodawcą (art. 19c-d ustawy o działalności). We Wrocławiu w 2016 r. ta forma była wykorzystywana dla organizowania osiedlowych festynów, „sąsiadówek”, osiedlowych turniejów sportowych czy upiększeń przestrzeni na osiedlach ${ }^{25}$.

5) Wzajemne informowanie się stron o planowanych kierunkach działalności (art. 5 ust. 2 pkt 2 ustawy o działalności).

6) Tworzenie jednostek organizacyjnych udzielających wsparcia w działalności organizacji pozarządowych we wszelkich aspektach (art. 5 ust. 2 pkt 6 ustawy

23 Przy Marszałku Województwa Dolnośląskiego istnieje Dolnośląska Rada Pożytku Publicznego — http://www.umwd.dolnyslask.pl (dostęp: 27.06.2017). We Wrocławiu funkcjonuje również Wrocławska Rada Działalności Pożytku Publicznego, funkcjonująca od 2005 r. — https://www. wroclaw.pl (dostęp: 17.09.2017).

24 http://www.wroclaw.pl/rozmawia/grupy-dialogu-spolecznego (dostęp: 17.09.2017).

25 Szczegółowe opisy wydarzeń realizowanych przez inicjatywy lokalne w 2016 r. można znaleźć na http://www.wroclaw.pl/inicjatywy-lokalnych-spolecznosci-we-wroclawiu-w-2016-r (dostęp: 17.09.2017). 
o działalności). We Wrocławiu działa Wrocławskie Centrum Wspierania Organizacji Pozarządowych SEKTOR 3, udzielające wsparcia powstającym i działającym organizacjom pozarządowym w wielu aspektach (m.in. doradztwo prawne, księgowe, szkolenia, warsztaty dla młodych organizacji pozarządowych, udostępnianie adresu siedziby, pomieszczeń konferencyjnych czy sprzętu komputerowego) ${ }^{26}$.

7) Przekazywanie do użytkowania organizacji pozarządowych, posiadających status organizacji pożytku publicznego, nieruchomości należących do Skarbu Państwa albo JST (art. 13 ust. 1a Ustawy z dnia 21 sierpnia 1997 r. o gospodarce nieruchomościami ${ }^{27}$ ). Na terenie miasta Wrocławia działają organizacje pozarządowe, które użytkują nieruchomości przekazane przez miasto Wrocław. Często dla początkujących organizacji siedzibą jest samo Wrocławskie Centrum Wspierania Organizacji Pozarządowych SEKTOR 3, które użycza młodym organizacjom pozarządowym swojego adresu/siedziby i adresu do korespondencji, numeru telefonu i miejsca na serwerze ${ }^{28}$.

8) Zlecanie obsługi otwartych konkursów ofert, o których była mowa powyżej, przeprowadzanych w celu wyłonienia organizacji wykonujących zlecane zadania publiczne (art. 11 ust. 2a-b ustawy o działalności). Organizacje mogą przeprowadzać takie konkursy poza enumeratywnie wymienionymi czynnościami, takimi jak m.in. ogłoszenie samego konkursu, powołanie komisji konkursowej czy zawarcie umowy z wyłonionym podmiotem.

9) Uchwalanie przez organy stanowiące JST rocznych (i możliwość uchwalania wieloletnich) programów współpracy JST z organizacjami pozarządowymi (art. 5a ustawy o działalności). Jest to jedna $\mathrm{z}$ niewielu obowiązkowych form współpracy. Uchwalane programy muszą być obowiązkowo konsultowane z organizacjami pozarządowymi działającymi na terenie danej JST. W przypadku miasta Wrocławia od 2017 r. obowiązuje Uchwała nr XXXI/635/16 Rady Miejskiej Wrocławia z dnia 20 października 2016 r. w sprawie Programu współpracy Miasta Wrocławia z organizacjami pozarządowymi w $2017 \mathrm{r} .{ }^{29}$ Natomiast wieloletni plan współpracy miasta Wrocławia z organizacjami pozarządowymi obowiązuje od 2013 r. na podstawie Uchwały nr XLII/981/13 z dnia 18 kwietnia 2013 r. w sprawie wieloletniego programu współpracy Miasta Wrocławia z organizacjami pozarządowymi w latach $2013-2017^{30}$.

Do innych niż zawarte w ustawie o działalności pozafinansowych form współpracy należą:

26 http://www.sektor3.wroclaw.pl/ (dostęp: 27.06.2017).

27 Tekst jedn. Dz.U. z 2016 r. poz. 2147.

28 Siedzibę ma tam np. „Fundacja Estyma”, działająca w środowisku osób niepełnosprawnych, ze szczególnym uwzględnieniem osób niewidomych i niedowidzących.

29 Biuletyn Urzędowy RMW z 2016 r. poz. 260.

30 Biuletyn Urzędowy RMW z 2013 r. poz. 151. 
1) Zawieranie umów o wspólną realizację określonych przedsięwzięć. Robert Barański podnosi jednak, że „zdaniem niektórych ekspertów, nie ma to podstawy prawnej"31.

2) Udzielanie merytorycznego wsparcia przy pozyskiwaniu innych źródeł finansowania.

3) Współpraca przy identyfikacji potrzeb społecznych i wypracowywaniu metod ich zaspokajania.

4) Udzielanie pomocy np. w zakresie współpracy z mediami czy z organizacjami o podobnym profilu działalności w innych krajach.

Jak wskazano, katalog form niefinansowych współpracy jest otwarty i dynamiczny. Powyższy przegląd jest jedynie pewnym zarysem możliwości współpracy.

\section{Podsumowanie}

W niniejszym artykule został dokonany przegląd form współpracy między administracją publiczną a organizacjami pozarządowymi, których najliczniejszymi reprezentantami są stowarzyszenia i fundacje. Przedstawiono konstrukcję prawną fundacji oraz stowarzyszenia i ukazano różnice konstrukcyjne między nimi. Sama administracja publiczna została natomiast zdefiniowana poprzez wskazanie jej cech charakterystycznych.

Więcej miejsca poświęcono finansowym formom współpracy, gdyż to one są jak na razie częściej wykorzystywane przez administrację publiczną. Dominuje zlecanie zadań publicznych organizacjom trzeciego sektora. Formy niefinansowe są z kolei znacznie liczniejsze, aczkolwiek — jak wskazuje się w literaturze - są również mniej doceniane przez organy administracji publicznej. Jak konstatuje R. Barański:

Powszechnym zjawiskiem jest niedocenianie przez obie strony współpracy znaczenia jej form niefinansowych (np. udziału organizacji non profit w tworzeniu aktów normatywnych, wzajemnego informowania się o planowanych kierunkach działalności) i skupianie się głównie na wspieraniu i powierzaniu realizacji zadań publicznych. Przyczyną takiego stanu rzeczy jest, jak się zdaje, brak świadomości stron współpracy korzyści, jakie współpraca pozafinansowa może im przynieść, jak również obawa przed ograniczeniem ich suwerenności ${ }^{32}$.

Pocieszające jest, że znajdowane są kolejne formy współpracy, a liczba organizacji pozarządowych rośnie (pomimo wskazywanych trudności dla powstających NGO).

\footnotetext{
31 R. Barański, op. cit., s. 356.

32 Ibidem, s. 523.
} 


\title{
Forms of cooperation between public administration and non-governmental organizations, on the example of associations and foundations
}

\begin{abstract}
Summary
The article describes relations and forms of cooperation between public administration bodies, both government and local government administration, and non-governmental organizations (NGOs) belonging to the so-called "Third sector". Associations and foundations are the most popular forms of NGOs. The basis for their functioning are the Constitution of the Republic of Poland, which guarantees freedom of association and foundation, and relevant acts, i.e. Law of Foundations and Law of Associations. There is no single, closed definition of the terms: public administration and administrative body. In literature they are defined by an indication of their characteristic features. We distinguish two forms of cooperation between the third sector and public administration: financial and non-financial. Financial support forms include targeted donations to NGO's public tasks, financial guarantees, loans and sureties given to perform public service tasks. The range of non-financial forms of cooperation includes among others consultations with non-governmental organizations on formulating legal acts related to their statutory activities, the establishment of joint advisory boards, the creation of units supporting the activities of third sector organizations, or the transfer of real estate to be used by non-governmental organizations.
\end{abstract}

Keywords: public administration, non-governmental organizations, foundations, associations, cooperation. 